LAWRENCE LIVERMORE N A T IO N A L LABORATORY
General and Localized Corrosion of Austenitic And Borated Stainless Steels in Simulated Concentrated Ground Waters

David V. Fix, John C. Estill, Lana L. Wong, Raul B. Rebak

March 15, 2004

ASME - Pressure Vessels and Piping San Diego, CA, United States July 25, 2004 through July 29, 2004 
This document was prepared as an account of work sponsored by an agency of the United States Government. Neither the United States Government nor the University of California nor any of their employees, makes any warranty, express or implied, or assumes any legal liability or responsibility for the accuracy, completeness, or usefulness of any information, apparatus, product, or process disclosed, or represents that its use would not infringe privately owned rights. Reference herein to any specific commercial product, process, or service by trade name, trademark, manufacturer, or otherwise, does not necessarily constitute or imply its endorsement, recommendation, or favoring by the United States Government or the University of California. The views and opinions of authors expressed herein do not necessarily state or reflect those of the United States Government or the University of California, and shall not be used for advertising or product endorsement purposes. 
11 March 2004

Paper to be presented at the American Society of Mechanical Engineers Pressure Vessels and Piping

Division (ASME-PVP) Conference in San Diego, CA 25-29 July 2004.

\title{
GENERAL AND LOCALIZED CORROSION OF AUSTENITIC AND BORATED STAINLESS STEELS IN SIMULATED CONCENTRATED GROUND WATERS
}

\author{
David V. Fix \\ John C. Estill \\ Lana L. Wong \\ Raúl B. Rebak \\ Lawrence Livermore National Laboratory \\ 7000 East Ave, L-631 \\ Livermore, California, 94550 USA
}

\begin{abstract}
Boron containing stainless steels are used in the nuclear industry for applications such as spent fuel storage, control rods and shielding. It was of interest to compare the corrosion resistance of three borated stainless steels with standard austenitic alloy materials such as type 304 and 316 stainless steels. Tests were conducted in three simulated concentrated ground waters at $90^{\circ} \mathrm{C}$. Results show that the borated stainless were less resistant to corrosion than the witness austenitic materials. An acidic concentrated ground water was more aggressive than an alkaline concentrated ground water.

Keywords: S30400, S31600, Borated Stainless Steel, Neutrosorb, Neutronit, Concentrated Ground Water, Localized Corrosion, $\mathrm{pH}$
\end{abstract}

\section{INTRODUCTION}

It is planned to store some 70,000 metric tons of nuclear waste in a repository located in Yucca Mountain, Nevada (1, 2 ). The safe disposal of radioactive waste requires that the waste be isolated from the environment until radioactive decay has reduced its toxicity to innocuous levels for plants, animals and humans. Engineered barriers are designed to limit the diffusion of the radioactive material to the surrounding geologic formation. The barriers may consist, for example, in a series of dissimilar materials such as zircaloy, glass, stainless steel, nickel alloy container and titanium drip shield. The spent fuel itself will be located inside the containers in structural inserts or baskets made of corrosion resistant alloys containing neutron absorber elements (neutron poisons) such as boron or gadolinium, which will control criticality (3-5). The use of gadolinium may be preferred because of the lower thermal neutron absorption properties of boron (5).

The corrosion rate of Neutrosorb Plus and Neutronit A976 were compared to the corrosion rate of witness 304L SS using $96 \mathrm{~h}$ immersion corrosion tests (3). Testing was carried out in a solution containing $0.01 \mathrm{M}$ formic acid plus $0.01 \mathrm{M}$ sodium formate plus $0.02 \mathrm{M}$ sodium oxalate plus $0.01 \mathrm{M}$ nitric acid plus $0.01 \mathrm{M}$ sodium chloride plus $0.01 \mathrm{M}$ hydrogen peroxide in distilled water at $90^{\circ} \mathrm{C}$. The $\mathrm{pH}$ of the solution was 4.06 . Results show that the corrosion rate of $304 \mathrm{~L}$ SS was 10 $\mu \mathrm{m} / \mathrm{year}$, that of Neutronit A976 was $40 \mu \mathrm{m} / \mathrm{year}$ and that of Neutrosorb was $60 \mu \mathrm{m} /$ year (3).

Waters that contact the engineered barriers (EB) are expected to be in the form of a multi-ionic solution. This solution may form through two different mechanisms: (1) Dripping from the drift wall and concentrating on the surface of the EB and (2) Deliquescence of salts (dust) that may accumulate on top of the EB during dry periods. In both cases, the aqueous solution would be concentrated. The ground waters associated with the Yucca Mountain region have been well characterized $(2,6)$. Table 1 shows the composition of saturated zone water (from a well designated J-13) from near the repository site. The J-13 well water is near-neutral and bicarbonate-rich with significant concentrations of sulfate, nitrate, chloride, alkalis and alkaline earths ions. Table 1 also shows the composition of three laboratory-prepared, aqueous, 
concentrated electrolyte solutions in which testing was performed. These electrolyte solutions range from $\mathrm{pH} \sim 3$ to 10 and are designated as simulated acidified water (SAW), simulated concentrated water (SCW) and simulated cement modified water (SCMW).

The purpose of the present work was to determine the corrosion behavior of three borated stainless steels and compare the results with the behavior of witness materials such as 304 and 316 austenitic stainless steels. Immersion testing was conducted for more than a 5-year in the concentrated simulated ground water at $90^{\circ} \mathrm{C}$ using weight (mass) loss coupons.

\section{EXPERIMENTAL PROCEDURE}

The corrosion behavior of types 304, 316 and of three borated stainless steels was determined using standard immersion tests according to ASTM G 30 and G 1. The tests were conducted in the Long Term Corrosion Test Facility (LTCTF) at the Lawrence Livermore National Laboratory (LLNL) (7). The test vessels are rather large and each is halffilled with $1000 \mathrm{~L}$ of solution. The immersion tests were carried out in three different electrolyte solutions simulating concentrated ground waters. The solutions were called SAW (Simulated Acidified Water), SCW (Simulated Concentrated Water) and SCMW (Simulated Cement Modified Water) (Table 1). Each of the simulated solutions used in this study are concentrated variations of J-13 well water (Table 1). The coupons were immersed in the liquid phase, suspended in the vapor phase above the water line in the vessels and also at the water line itself. The nominal testing temperature was $90^{\circ} \mathrm{C}$ for the liquid phase. The simulated electrolyte solutions were naturally aerated, i.e., the solutions were not purged and the ingress of air above the solution was not restricted. All tests were carried out under ambient pressure.
The corrosion test coupons of 304 and 316 SS measured nominally 2 in. $\times 1$ in. $\times 1 / 16$ in. (approximately $50 \mathrm{~mm} \times 25$ $\mathrm{mm} \times 1.5 \mathrm{~mm}$ ) and the borated stainless steels coupons (SSN and SSE) measured nominally 1 in. $\times 1$ in. $\times 1 / 8$ in. $(25 \mathrm{~mm} \times$ $25 \mathrm{~mm} \times 3 \mathrm{~mm})$. The $\mathrm{SSC}$ coupons were of the same dimensions but $2 \mathrm{~mm}$ thick (Table 2 for acronyms). The surface areas of the weight loss coupons varied from approximately 14$15 \mathrm{~cm}^{2}$ for the borated stainless to $28 \mathrm{~cm}^{2}$ for the witness materials. The initial weight (mass) of the coupons varied between 12 to $14 \mathrm{~g}$ for 304, 316, SSN and SSE steels and were approximately $9 \mathrm{~g}$ for the SSC coupons (which had a thickness of $2 \mathrm{~mm}$ ). The coupons were fabricated from industrial plate stock. The chemical composition and alloy designation of the five studied materials are given in Table 2. The type 304 (S30400) and 316 (S31600) stainless steels were standard wrought materials supplied by Metal Samples. S30400 and S31600 are used as witness materials. The density of 304 and $316 \mathrm{SS}$ are $7.94 \mathrm{~g} / \mathrm{cm}^{3}$ and $7.98 \mathrm{~g} / \mathrm{cm}^{3}$, respectively. The heat numbers of these witness austenitic materials are unavailable. Neutrosorb Plus was a material produced by powder metallurgy according to ASTM A 887 by Carpenter Technologies (8). The UNS number of Neutrosorb Plus is S30467 and its heat number is unavailable. S30467 has a composition like S30400 with $1.75 \%$ of added boron (Table 2). The density of S30467 is 7.77 $\mathrm{g} / \mathrm{cm}^{3}$. Neutronit alloys are wrought products of Bohler Bleche. These two alloys have a composition like 316 SS with 1.38 to $1.62 \%$ added boron. The heat numbers and compositions of Neutronit are given in Table 2. The density of the Neutronit stainless was unavailable and it was assumed to be $7.77 \mathrm{~g} / \mathrm{cm}^{3}$. The weight loss coupons had a central hole, which was used for affixing them to the racks in the vessels using a bolt and 1/2" diameter PTFE washers or spacers to avoid electrical contact between them. That is, all the coupons had a small annulus around the central hole with an unintended crevice or an area of the metal surface that was shielded from the bulk of the solution in the vessels.

Table 1. Chemical composition of the electrolyte solutions (mg/L)

\begin{tabular}{|c|c|c|c|c|}
\hline Ion & $\begin{array}{l}\text { SCMW } \\
\text { pH } 7.75\end{array}$ & $\begin{array}{c}\text { SCW } \\
\text { pH } 10.3\end{array}$ & $\begin{array}{l}\text { SAW } \\
\text { pH } 2.8\end{array}$ & $\begin{array}{c}\text { J-13 Well Water } \\
\text { pH } 7.4\end{array}$ \\
\hline $\mathbf{K}^{+}$ & 309 & 3400 & 3400 & 5.04 \\
\hline $\mathbf{N a}^{+}$ & 14 & 40,900 & 40,900 & 45.8 \\
\hline $\mathbf{M g}^{2+}$ & 0.3 & $<1$ & 1000 & 2.01 \\
\hline $\mathrm{Ca}^{2+}$ & 197.5 & $<1$ & 1000 & 13 \\
\hline $\mathbf{F}^{-}$ & 1.3 & 1400 & 0 & 2.18 \\
\hline $\mathrm{Cl}^{-}$ & 4.3 & 6700 & 24,250 & 7.14 \\
\hline $\mathrm{NO}_{3}^{-}$ & 5.2 & 6400 & 23,000 & 8.78 \\
\hline $\mathrm{SO}_{4}{ }^{2-}$ & 864.7 & 16,700 & 38,600 & 18.4 \\
\hline $\mathrm{HCO}_{3}^{-}$ & 6.4 & 70,000 & 0 & 128.9 \\
\hline $\mathrm{SiO}_{2}(\mathrm{aq})$ & $22.7(\mathrm{Si})$ & $\sim 40$ & $\sim 40$ & 61.1 \\
\hline
\end{tabular}


Table 2. Chemical composition of the studied stainless steel alloys (wt\%)

\begin{tabular}{lccccc}
\hline Element & $\begin{array}{c}\text { 304 SS } \\
(\text { S30400 })\end{array}$ & $\begin{array}{c}316 \mathrm{SS} \\
(\mathrm{S} 31600)\end{array}$ & $\begin{array}{c}\text { Neutrosorb Plus } \\
(\text { S30467) } \\
\text { Type 304B7 }\end{array}$ & $\begin{array}{c}\text { Neutronit A978 } \\
\text { Type 316B7 } \\
\text { (Heat E084295) }\end{array}$ & $\begin{array}{c}\text { Netronit A978 } \\
\text { Type 316B7 } \\
\text { (Heat N156129) }\end{array}$ \\
\hline Name & 304 & 316 & SSC & SSE & SSN \\
\hline $\mathrm{Fe}$ & $\sim 70.0$ & $\sim 68$ & $\sim 64$ & $\sim 64$ & $\sim 63$ \\
$\mathrm{Cr}$ & 18.98 & 16.55 & 19.97 & 18.18 & 19.16 \\
$\mathrm{Ni}$ & 8.02 & 10.70 & 12.49 & 12.07 & 12.74 \\
$\mathrm{Mo}$ & 0.14 & 2.13 & $<0.005$ & 2.11 & 2.22 \\
$\mathrm{~B}$ & --- & --- & $1.57(\mathrm{~A})$ & $1.00(\mathrm{~B})$ & $1.17(\mathrm{C})$ \\
$\mathrm{C}$ & 0.070 & 0.034 & 0.034 & 0.056 & 0.039 \\
$\mathrm{Mn}$ & 1.96 & 1.84 & 1.70 & 1.43 & 0.97 \\
$\mathrm{Cu}$ & 0.35 & 0.21 & 0.02 & 0.11 & 0.10 \\
$\mathrm{Si}$ & 0.48 & 0.57 & 0.60 & 0.72 & 0.38 \\
\hline
\end{tabular}

The nominal values are: (A) $1.75 \%$, (B) $1.38 \%$ and (C) $1.62 \%$.

The exposure time for the stainless steel specimens was over 5 years. The actual testing time for each vessel is shown in Table 3 along with each specimen label, vessel number and weight loss (or gain) during the testing period. Each specimen is designated with 3 letters or numbers (Table 2) followed by 2 characteristic sequential numbers. The results in Table 3 and further analysis are for dry specimens as removed from the vessels, that is, the specimens were not cleaned to remove corrosion products or salt deposits.

After more than five-year exposure to each solution at $90^{\circ} \mathrm{C}$, the specimens were removed from their respective test vessels, rinsed in DI water and dried in air at ambient temperature. In all of the tested conditions, the coupons were covered with deposits, which formed by precipitation of salts from the environment. In some environments, the coupons also had corrosion products. In the analyses given in this report, the coupons were not cleaned. That is, actual corrosion rates are not calculated. Relative corrosion rates may be calculated using Equation 1:

$$
C R(n m / y r)=\frac{8.76 \times 10^{10} \Delta W}{\rho \mathrm{A} t}
$$

where

$8.76 \times 10^{10}$ is the proportionality constant,

$\Delta W$ is the mass loss in grams after $5+$ years,

$\rho$ is the density of each of the stainless alloys in $\mathrm{g} / \mathrm{cm}^{3}$

$A$ is the exposed surface area of each coupon $\left(\mathrm{cm}^{2}\right)$ and $t$ is the exposure time (hours).

\section{RESULTS AND DISCUSSION}

Table 3 shows the weight loss (gain) of the tested stainless coupons. A total of 135 coupons were studied. Most of the coupons exposed to the vapor phase in each of the three vessels experienced weight gain due to the formation of deposits or corrosion products that cannot be fully washed out due to the restricted amount of condensed water. The coupons exposed to the water line had a distinctive behavior depending on the testing vessel. In the SAW vessel, most of the coupons suffered weight loss. The largest weight loss corresponded to the SSC coupons followed by the SSE/SSN coupons, then 304 SS and the lowest weight loss was for the 316 SS coupons (Table 3). In the SCW vessel, the coupons exposed to the water line also suffered weight loss, although a small amount compared to the SAW vessel. All the coupons exposed to the water line in the SCMW vessel experienced weight gain, mainly due to the heavy precipitation of a white/brown salt at the splash line (wet/dry) (Table 4). This salt is probably $\mathrm{CaSO}_{4}$ but this needs to be confirmed.

Most of the coupons exposed to the liquid phase suffered weight loss due to corrosion. SAW was the most aggressive solution for all the materials and the borated stainless suffered the largest amount of weight loss. The second most corrosive solution was SCMW, which especially corroded the SSE/SSN borated stainless. The least corrosive solution was $\mathrm{SCW}$, which caused little corrosion in the witness materials (304 and 316). The least resistant material in SCW seemed the powder metallurgy alloy SSC.

Figures 1 and 2 show the weight loss (gain) for the coupons tested in SAW and SCMW liquid, respectively. Assuming that the same amount of deposits forms on both the witness alloys and the borated stainless, Table 3 and Figure 1 


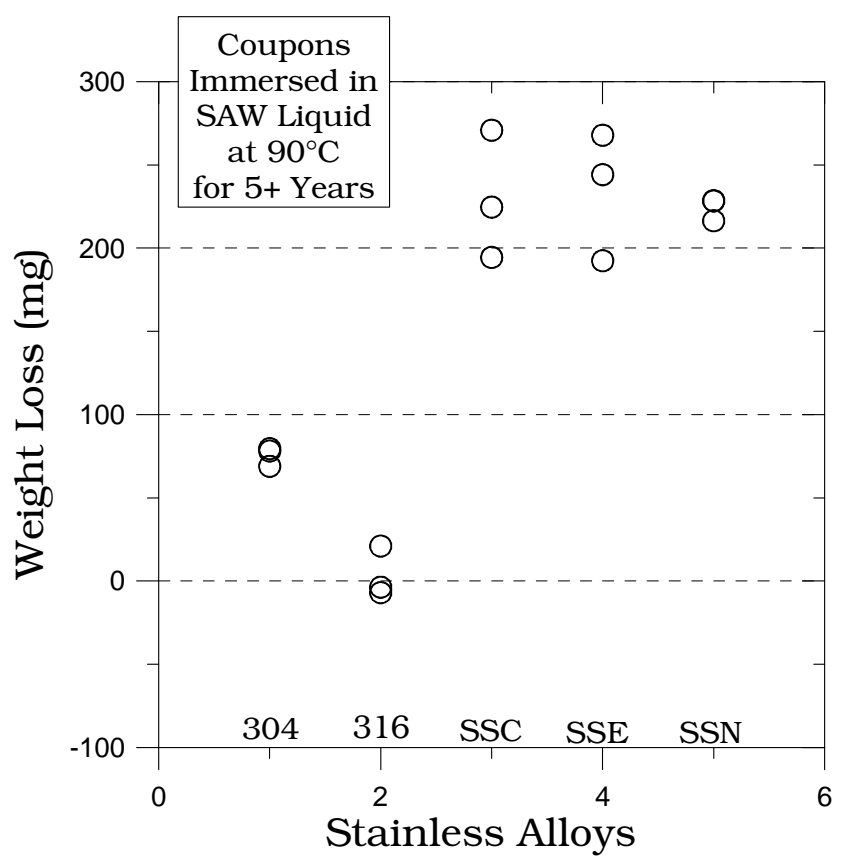

Figure 1. Weight Loss (Gain) for Coupons tested in SAW Liquid for over 5 years.

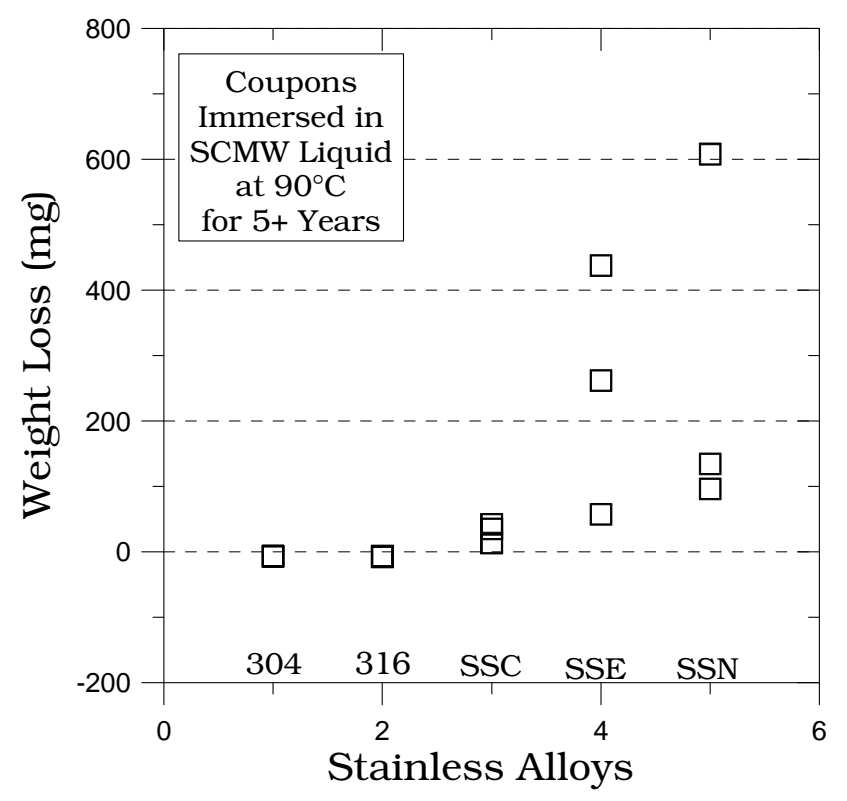

Figure 2. Weight Loss (Gain) for Coupons tested in SCMW Liquid for over 5 years. show that the borated stainless, in liquid SAW, lost 3 to 10 times more mass than the witness materials. This ration was even higher for SSE/SSN materials exposed to the liquid SCMW (Table 3 and Figure 2). Using equation 1, the approximate corrosion rates for the borated stainless steels (without cleaning) in liquid SAW is $3.5 \mu \mathrm{m} /$ year while the approximate corrosion rate for $304 \mathrm{SS}$ is $0.6 \mu \mathrm{m} / \mathrm{year}$. The calculation of these corrosion rates are given for comparative purposes only since most of the corrosion degradation was caused by localized attack in the annulus, that is, it is not justifiable to distribute the weight loss over the entire surface of the coupon to calculate a uniform penetration rate.

\section{MODE OF ATTACK IN CORRODED COUPONS}

Table 4 shows a description of the corroded coupons under an optical stereomicroscope. In general, results show that the borated stainless were less resistant to corrosion than the witness materials. For example, in liquid SAW, all the five tested materials suffered localized corrosion in the annulus region, but the attack was more extended in the borated materials. On the other hand, in liquid SCMW, the witness materials did not suffer localized corrosion while all the borated stainless had localized corrosion (Table 4). The least aggressive solution was liquid SCW since it only irregularly induced little localized corrosion in the borated stainless and none in the witness materials.

The localized corrosion resistance of stainless steels depends mainly on three factors: (1) Redox potential, (2) Temperature and (3) Chloride concentration and $\mathrm{pH}$. It can be assumed that the first two influencing factors are the same for the three vessels (SAW, SCW and SCMW). It may be obvious that SAW was the most aggressive electrolyte since it had the largest amount of chloride and the lowest $\mathrm{pH}$ (2.8) (Table 1). Even though SCW had more chloride concentration than SCMW, the former was probably less aggressive because its $\mathrm{pH}$ was higher (10.3)

Figures 3-5 show the corrosion of coupons of 316 , SSC and SSN materials in liquid SAW. All these materials suffered localized corrosion in the annulus region (shown) The corrosion products (oxides) inside the corrosion pits in Figure 3 are rich in $\mathrm{Mo}$ and $\mathrm{Cr}$. In the borates stainless, the corrosion action left behind particles of $\mathrm{Fe}$ and $\mathrm{Cr}$ borides. This was also evident in the corrosion of the boldly exposed surface of the borated stainless. For example, Figure 6 shows the boldly exposed surface of a SSC coupon corroded in liquid SCW solution. Corrosion around the iron and chromium boride particles is observed. 


\section{CONCLUSIONS}

The largest weight loss was in the liquid phase where corrosion products were washed away. Most of the coupons exposed to the vapor phase experienced weight gain

The highest corrosion rate for all materials was in the acidic liquid SAW solution

The lowest corrosion damage for all materials was in the alkaline SCW solution

All materials suffered localized corrosion in SAW solution

Only the borated stainless suffered localized corrosion in the SCW and SCMW solutions

The borated stainless in general suffered weight losses 3 to 10 times higher than the witness materials

Since weight loss was mostly caused by localized corrosion in the annulus, uniform penetration rates calculations are inappropriate

\section{ACKNOWLEDGMENTS}

This work was performed under the auspices of the U. S. Department of Energy by the University of California Lawrence Livermore National Laboratory under contract $\mathrm{N}^{\circ}$ W-7405-Eng-48. This work is supported by the Yucca Mountain Project, LLNL, which is part of the Office of Civilian Radioactive Waste Management, OCRWM-DOE

\section{REFERENCES}

1. Yucca Mountain Science and Engineering Report, U. S. Department of Energy, Office of Civilian Radioactive Waste Management, DOE/RW-0539, Las Vegas, NV, May 2001.

2. G. M. Gordon, Corrosion, 58, 811 (2002).

3. R. A. Van Konynemburg, P. G. Curtis and T. S. E. Summers "Scoping Corrosion Tests on Candidate Waste Package Basket Materials for the Yucca Mountain Project," Report UCRL-ID-130386 (Lawrence Livermore National Laboratory, 1998: Livermore, CA).

4. R. E. Mizia, T. E. Lister, P. J. Pinhero, J. N. DuPont and C. V. Robino, Corrosion/2001, paper 01138 (NACE International, 2001: Houston, TX).

5. R. E. Mizia, T. E. Lister, P. J. Pinhero, C. V. Robino and J. N. DuPont, Corrosion/2003, paper 03679 (NACE International, 2003: Houston, TX).

6. N.D. Rosenberg, G. E. Gdowski and K. G. Knauss. 2001. Applied Geochemistry, 16:1231.

7. L. L. Wong, D. V. Fix, J. C. Estill, R. D. McCright and R. B. Rebak, "Characterization of the Corrosion Behavior of Alloy 22 after Five Years Immersion in Multi-Ionic Solutions," Vol. 757, p 735-741 (Materials Research Society, 2003: Warrendale, PA).

8. ASTM Standard A 887-2000. "Standard Specification for Borated Stainless Steel Plate, Sheet and Strip for Nuclear Application," The Annual Book of the ASTM Standards, (ASTM, 2003: West Conshohocken, PA) 
Table 3. Tested Stainless Steel Coupons and Weight Loss (or Gain).

\begin{tabular}{|c|c|c|c|c|c|c|}
\hline & $\begin{array}{l}\text { SAW, } \\
90^{\circ} \mathrm{C}\end{array}$ & $\begin{array}{l}\text { Weight Loss } \\
\text { (Gain) in } \mathrm{mg}\end{array}$ & $\begin{array}{l}\mathrm{SCW} \\
90^{\circ} \mathrm{C}\end{array}$ & $\begin{array}{l}\text { Weight Loss } \\
\text { (Gain) in } \mathrm{mg}\end{array}$ & $\begin{array}{c}\text { SCMW, } \\
90^{\circ} \mathrm{C}\end{array}$ & $\begin{array}{l}\text { Weight Loss } \\
\text { (Gain) in mg }\end{array}$ \\
\hline Vessel & 26 & 26 & 28 & 28 & $18(32)$ & $18(32)$ \\
\hline \multicolumn{7}{|l|}{ Vapor } \\
\hline & $304-11$ & $(28.2)$ & $304-20$ & (5) & $304-82$ & $(0.8)$ \\
\hline & $304-12$ & 64.1 & $304-41$ & (6) & $304-83$ & (0.6) \\
\hline & $304-13$ & $(37.4)$ & $304-42$ & (1.5) & $304-84$ & (1.0) \\
\hline & $316-03$ & $(0.6)$ & $316-53$ & (4.4) & $316-92$ & $(0.7)$ \\
\hline & 316-04 & $(0.9)$ & 316-54 & $(3.3)$ & $316-93$ & $(0.8)$ \\
\hline & $316-05$ & $(0.5)$ & $316-55$ & (1.9) & $316-94$ & $(0.9)$ \\
\hline & SSC-01 & 37.1 & SSC-10 & (1.0) & SSC-21 & $(0.4)$ \\
\hline & SSC-02 & $(29.5)$ & SSC-12 & $(1.7)$ & SSC-22 & $(0.3)$ \\
\hline & SSC-03 & (36.8) & SSC-13 & (1.7) & SSC-23 & 0.1 \\
\hline & SSE-01 & (49) & SSE-12 & (1.5) & SSE-22 & $(0.5)$ \\
\hline & SSE-02 & 18.5 & SSE-13 & (4.1) & SSE-23 & $(0.3)$ \\
\hline & SSE-03 & $(79.2)$ & SSE-15 & (3.4) & SSE-24 & $(2.4)$ \\
\hline & SSN-02 & $(29.7)$ & SSN-11 & 0.6 & SSN-21 & 1.1 \\
\hline & SSN-03 & $(42.1)$ & SSN-12 & $(0.5)$ & SSN-23 & $\begin{array}{l}(0.2) \\
\end{array}$ \\
\hline & SSN-04 & $(21.3)$ & SSN-13 & (1.9) & SSN-24 & 0.1 \\
\hline \multicolumn{7}{|c|}{ Water Line } \\
\hline & $304-17$ & 49.5 & $304-46$ & 1.2 & $304-88$ & $(135.3)$ \\
\hline & $304-18$ & 47.0 & $304-47$ & 0.7 & $304-89$ & (148.3) \\
\hline & 304-19 & 62.7 & $304-81$ & 1.5 & $304-90$ & $(142.8)$ \\
\hline & 316-09 & 17.3 & $316-59$ & 1.7 & $316-98$ & $(132.0)$ \\
\hline & $316-51$ & 36.4 & $316-60$ & 1.6 & $316-99$ & $(158.0)$ \\
\hline & $316-52$ & 32.3 & $316-91$ & 2.0 & $316-100$ & (149.3) \\
\hline & SSC-07 & 154.7 & SSC-18 & 5.7 & SSC-27 & (163.2) \\
\hline & SSC-08 & 130.2 & SSC-19 & 5.1 & SSC-28 & $(77.1)$ \\
\hline & SSC-09 & 136.0 & SSC-20 & 5.2 & SSC-30 & $(154.4)$ \\
\hline & SSE-09 & 61.1 & SSE-19 & 5.7 & SSE-28 & $(88.7)$ \\
\hline & SSE-10 & 112.3 & SSE-20 & 5.7 & SSE-29 & $(163.5)$ \\
\hline & SSE-11 & 129.7 & SSE-21 & 5.0 & SSE-30 & $(35.1)$ \\
\hline & SSN-08 & 69.6 & SSN-18 & 0.7 & SSN-28 & $(139.9)$ \\
\hline & SSN-09 & 133.6 & SSN-19 & 2.8 & SSN-29 & $\begin{array}{l}(88.0) \\
\end{array}$ \\
\hline & SSN-10 & 108.1 & SSN-20 & 2.1 & SSN-30 & (137.6) \\
\hline \multicolumn{7}{|l|}{ Liquid } \\
\hline & $304-14$ & 78.1 & $304-43$ & 0.5 & $304-85$ & (6.7) \\
\hline & $304-15$ & 79.5 & 304-44 & 0.7 & $304-86$ & $(6.2)$ \\
\hline & $304-16$ & 68.9 & $304-45$ & 1.6 & $304-87$ & $(6.4)$ \\
\hline & 316-06 & (3.7) & $316-56$ & 0.7 & $316-95$ & $(7.2)$ \\
\hline & $316-07$ & 21.0 & $316-57$ & 0.6 & $316-96$ & (6.2) \\
\hline & $316-08$ & $(7.0)$ & 316-58 & 1.9 & $316-97$ & $(7.5)$ \\
\hline & SSC-04 & 270.8 & SSC-14 & 44.0 & SSC-24 & 42.2 \\
\hline & SSC-05 & 224.6 & SSC-15 & 312.7 & SSC-25 & 13.5 \\
\hline
\end{tabular}




\begin{tabular}{|c|c|c|c|c|c|c|}
\hline & SSC-06 & 194.4 & SSC-17 & 8.6 & SSC-26 & 35.5 \\
\hline & SSE-05 & 244.1 & SSE-16 & 8.8 & SSE-25 & 262.1 \\
\hline & SSE-06 & 267.8 & SSE-17 & 8.3 & SSE-26 & 57.6 \\
\hline & SSE-08 & 192.4 & SSE-18 & 9.4 & SSE-27 & 437.9 \\
\hline & SSN-05 & 228.3 & SSN-15 & 3.4 & SSN-25 & 96.4 \\
\hline & SSN-06 & 216.4 & SSN-16 & 3.3 & SSN-26 & 608.1 \\
\hline & SSN-07 & 228.5 & SSN-17 & 3.4 & SSN-27 & 134.7 \\
\hline Date in & 03Mar1998 & & 03Mar1998 & & 03Mar1998 & \\
\hline Date out & 06Jan2004 & & $20 \mathrm{Aug} 2003$ or $06 \mathrm{Jan} 2004$ & & 06Jan2004 & \\
\hline $\begin{array}{l}\text { Exp. Time, } \\
\text { days (h) }\end{array}$ & $2,134(51,216)$ & & $\begin{array}{l}1,994(47,856) \text { for } 304 \text { and } \\
316 \mathrm{SS} ; 2,134(51,216) \text { for } \\
\text { the Borated Alloys }\end{array}$ & & $2,134(51,216)$ & \\
\hline
\end{tabular}

Table 4. Low Magnification (20X) Optical Observation of the Corroded Coupons

\begin{tabular}{|c|c|c|c|}
\hline & $\begin{array}{l}\text { SAW, } \\
90^{\circ} \mathrm{C}\end{array}$ & $\begin{array}{l}\mathrm{SCW}, \\
90^{\circ} \mathrm{C}\end{array}$ & $\begin{array}{c}\mathrm{SCMW}, \\
90^{\circ} \mathrm{C}\end{array}$ \\
\hline Vessel & 26 & 28 & $18(32)$ \\
\hline \multicolumn{4}{|l|}{ Vapor } \\
\hline $304 \mathrm{SS}$ & $\begin{array}{l}\text { Spotted or stained, multicolor } \\
\text { (brown, green, yellow, purple). No } \\
\text { apparent general or localized } \\
\text { corrosion }\end{array}$ & $\begin{array}{l}\text { Dark blue/coal with areas of intense } \\
\text { rust color. Abundant deposits (or } \\
\text { corrosion products). No apparent } \\
\text { localized corrosion. }\end{array}$ & $\begin{array}{l}\text { Shiny metallic with a thin veil of } \\
\text { brown and yellow deposits. No } \\
\text { general or localized corrosion }\end{array}$ \\
\hline $316 \mathrm{SS}$ & $\begin{array}{l}\text { Coupons shiny gray with } \\
\text { yellow/brown spots. Other spots red } \\
\text { and green. No apparent general } \\
\text { corrosion in the boldly exposed } \\
\text { surface. }\end{array}$ & $\begin{array}{l}\text { Dark gray and rusty in patches. } \\
\text { Some areas of plum color. } \\
\text { Accumulation of concentric deposits } \\
\text { in annulus }\end{array}$ & $\begin{array}{l}\text { Shiny gray with spots of yellow/rust } \\
\text { color. Small amount of deposits. No } \\
\text { apparent general or localized } \\
\text { corrosion }\end{array}$ \\
\hline Neutrosorb & $\begin{array}{l}\text { Coupons covered by large amount } \\
\text { of black, glass like, deposits. Also } \\
\text { red, yellow and blue spots }\end{array}$ & $\begin{array}{l}\text { Brown/yellow in patches with light } \\
\text { shiny gray in between. Little crevice } \\
\text { corrosion in annulus }\end{array}$ & $\begin{array}{l}\text { Shiny light brown, spotted in brown. } \\
\text { Crevice corrosion in annular section, } \\
\text { cracks from hole }\end{array}$ \\
\hline Neutronit E & $\begin{array}{l}\text { Dark gray/greenish. Shiny black } \\
\text { glassy like deposits. Crevice } \\
\text { corrosion in annulus }\end{array}$ & $\begin{array}{l}\text { Shiny gray in spots. Rust like } \\
\text { deposits. Some apparent general } \\
\text { corrosion. Negligible crevice } \\
\text { corrosion }\end{array}$ & $\begin{array}{l}\text { Gray/stained, with some wet-like } \\
\text { spots. No obvious general or } \\
\text { localized corrosion. }\end{array}$ \\
\hline Neutronit $\mathrm{N}$ & $\begin{array}{l}\text { Light dull gray. Scattered glass like } \\
\text { black deposits. Also brown and } \\
\text { yellow depostis. Crevice corrosion } \\
\text { in annulus }\end{array}$ & $\begin{array}{l}\text { Spotted dark gray, brown (rusty). } \\
\text { Difficult to assess general corrosion } \\
\text { due to deposits. Little or no crevice } \\
\text { corrosion }\end{array}$ & $\begin{array}{l}\text { Dark gray spotted with yellow and } \\
\text { purple areas. Little or no crevice } \\
\text { corrosion }\end{array}$ \\
\hline \multicolumn{4}{|l|}{$\begin{array}{l}\text { Water } \\
\text { Line }\end{array}$} \\
\hline $304 \mathrm{SS}$ & $\begin{array}{l}\text { Pitting corrosion in annulus. One } \\
\text { large bump with accumulated } \\
\text { corrosion products (oxides) in each } \\
\text { coupon. Stains in vapor phase, clear } \\
\text { shiny in liquid phase. }\end{array}$ & $\begin{array}{l}\text { Light golden in vapor phase. Clear } \\
\text { at water line. Dark gray/bluish in } \\
\text { liquid. No apparent general or } \\
\text { localized corrosion }\end{array}$ & $\begin{array}{l}\text { Thick crust of white/brown deposits } \\
\text { above water line. Fewer deposits in } \\
\text { liquid phase. No apparent general or } \\
\text { localized corrosion }\end{array}$ \\
\hline
\end{tabular}




\begin{tabular}{|c|c|c|c|}
\hline $316 \mathrm{SS}$ & $\begin{array}{l}\text { Coupons dull with little deposits. No } \\
\text { apparent corrosion in boldly } \\
\text { exposed surface. Extensive attack in } \\
\text { the annulus region. Each coupon has } \\
\text { one large pit with accumulated } \\
\text { corrosion products which perforated } \\
\text { the thickness. }\end{array}$ & $\begin{array}{l}\text { Light golden in vapor phase, clear in } \\
\text { water line and bright coal/blue in } \\
\text { liquid. Concentric deposits in } \\
\text { annulus. No apparent corrosion }\end{array}$ & $\begin{array}{l}\text { Dark brown caked with brown and } \\
\text { yellow salt like deposits, especially } \\
\text { in the wet/dry area. Clear annulus } \\
\text { and no apparent localized corrosion }\end{array}$ \\
\hline Neutrosorb & $\begin{array}{l}\text { The area exposed to the vapor was } \\
\text { dark brown with black glassy } \\
\text { deposits. The are in the liquid was } \\
\text { light gray. Extensive crevice } \\
\text { corrosion in the annulus }\end{array}$ & $\begin{array}{l}\text { Shiny golden in vapor phase, shiny } \\
\text { dark gray and bluish in liquid. Little } \\
\text { crevice corrosion in annulus }\end{array}$ & $\begin{array}{l}\text { Top half caked with brown/white } \\
\text { deposits. Little crevice corrosion in } \\
\text { annulus and cracks from hole. }\end{array}$ \\
\hline Neutronit E & $\begin{array}{l}\text { Shiny black/brown with large } \\
\text { amount of deposits and corrosion } \\
\text { products. Crevice corrosion in } \\
\text { annulus. White salt like deposits in } \\
\text { entire surface }\end{array}$ & $\begin{array}{l}\text { Dark gray with deposits. General } \\
\text { corrosion outside annulus. Little } \\
\text { crevice corrosion }\end{array}$ & $\begin{array}{l}\text { White deposits in wet/dry area. } \\
\text { Large amounts of black and brown } \\
\text { deposits (or corrosion products). } \\
\text { Shiny glassy black products. } \\
\text { Extensive crevice corrosion in } \\
\text { annulus. }\end{array}$ \\
\hline Neutronit $\mathrm{N}$ & $\begin{array}{l}\text { In vapor phase caked black and } \\
\text { brown deposits. In liquid phase light } \\
\text { dull gray. Sugary crevice corrosion } \\
\text { in annulus }\end{array}$ & $\begin{array}{l}\text { Tan in the vapor phase. Even gray in } \\
\text { the liquid phase. White deposits } \\
\text { around annulus. Not obvious crevice } \\
\text { corrosion. Probably general } \\
\text { corrosion }\end{array}$ & $\begin{array}{l}\text { Caked with white deposits in } \\
\text { wet/dry area. Dark brown/black in } \\
\text { the liquid phase. Extensive sugar } \\
\text { like crevice corrosion with glassy } \\
\text { black corrosion products }\end{array}$ \\
\hline \multicolumn{4}{|l|}{ Liquid } \\
\hline $304 \mathrm{SS}$ & $\begin{array}{l}\text { Coupons dull gray. Brown and black } \\
\text { deposits over entire surface. One } \\
\text { large bump with corrosion products } \\
\text { in each coupon. Pitting corrosion in } \\
\text { annulus. }\end{array}$ & $\begin{array}{l}\text { Dark gray/bluish, shiny. Little or no } \\
\text { deposits. No apparent general or } \\
\text { localized corrosion }\end{array}$ & $\begin{array}{l}\text { On label side, brown oily or wet } \\
\text { appearance. On the back side, the } \\
\text { same appearance of wetness but less } \\
\text { rusty. No apparent general or } \\
\text { localized corrosion }\end{array}$ \\
\hline $316 \mathrm{SS}$ & $\begin{array}{l}\text { Corrosion attack in the liquid phase } \\
\text { is less pronounced that in the water } \\
\text { line. Two coupons had corrosion } \\
\text { pits in the annulus which perforated } \\
\text { the thickness. Brown/white deposits } \\
\text { at inferface }\end{array}$ & $\begin{array}{l}\text { Dark gray/bluish shiny. White } \\
\text { concentric deposits in annulus. No } \\
\text { general or localized corrosion }\end{array}$ & $\begin{array}{l}\text { Brown wet with oily appearance. } \\
\text { Clear annular section. No apparent } \\
\text { general or localized corrosion }\end{array}$ \\
\hline Neutrosorb & $\begin{array}{l}\text { Light gray coupon. White deposits. } \\
\text { Extensive crevice corrosion in } \\
\text { annulus. Some pieces of the annulus } \\
\text { might have fallen off. Black glass } \\
\text { like crystals }\end{array}$ & $\begin{array}{l}\text { Shiny dark gray and blue. Shallow } \\
\text { cracks from hole. Crevice corrosion } \\
\text { in annulus }\end{array}$ & $\begin{array}{l}\text { Dark brown/rusty with patches of } \\
\text { cobalt blue. Extensive pitting and } \\
\text { crevice corrosion in annulus. } \\
\text { Delamination and cracks at hole }\end{array}$ \\
\hline Neutronit E & $\begin{array}{l}\text { Light gray. Extensive crevice } \\
\text { corrosion in annulus leaving behind } \\
\text { a sugar like appearance. Black } \\
\text { deposits around the hole }\end{array}$ & $\begin{array}{l}\text { Even dark gray. Little deposits, } \\
\text { some general corrosion, little crevice } \\
\text { corrosion }\end{array}$ & $\begin{array}{l}\text { Large mounds of crumbling rust } \\
\text { especially by the hole. Extensive } \\
\text { crevice corrosion in annulus. Shiny } \\
\text { black glassy appearance of corrosion } \\
\text { products. Wet oily appearance in } \\
\text { label side. }\end{array}$ \\
\hline Neutronit N & $\begin{array}{l}\text { Light dull gray with black and } \\
\text { yellow deposits. Extensive sugary } \\
\text { crevice corrosion in annulus. Some } \\
\text { cracks from hole }\end{array}$ & $\begin{array}{l}\text { Uniform dark gray, little apparent } \\
\text { crevice corrosion. General corrosion } \\
\text { in boldly exposed surface. }\end{array}$ & $\begin{array}{l}\text { Gray with brown deposits. } \\
\text { Extensive crevice corrosion in } \\
\text { annulus. Plenty of brown/black } \\
\text { corrosion products. }\end{array}$ \\
\hline
\end{tabular}




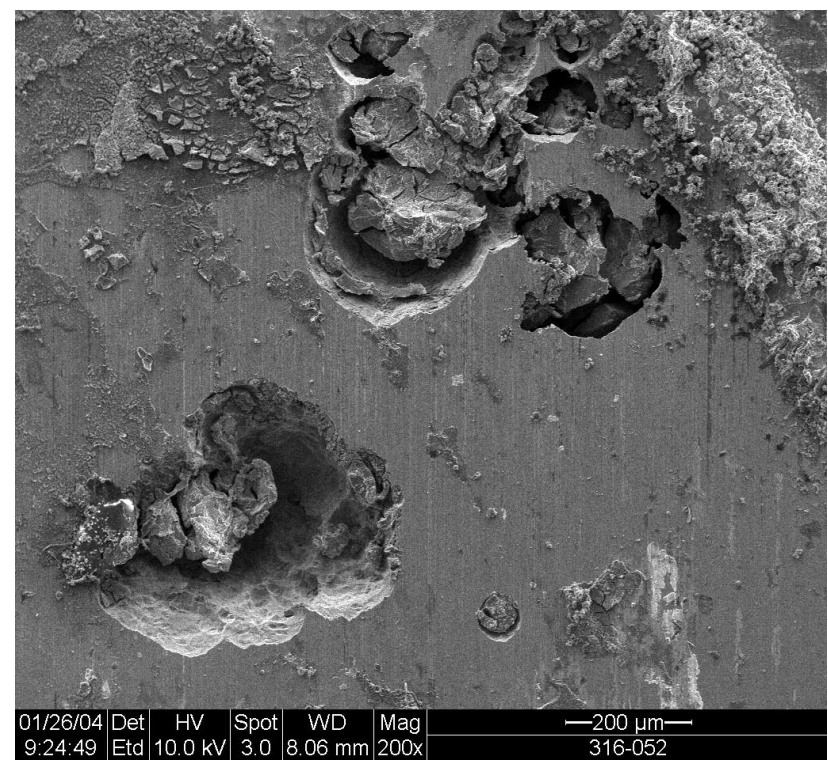

Figure 3: Annulus of 316-52 in SAW, Liquid for $5+$ Years

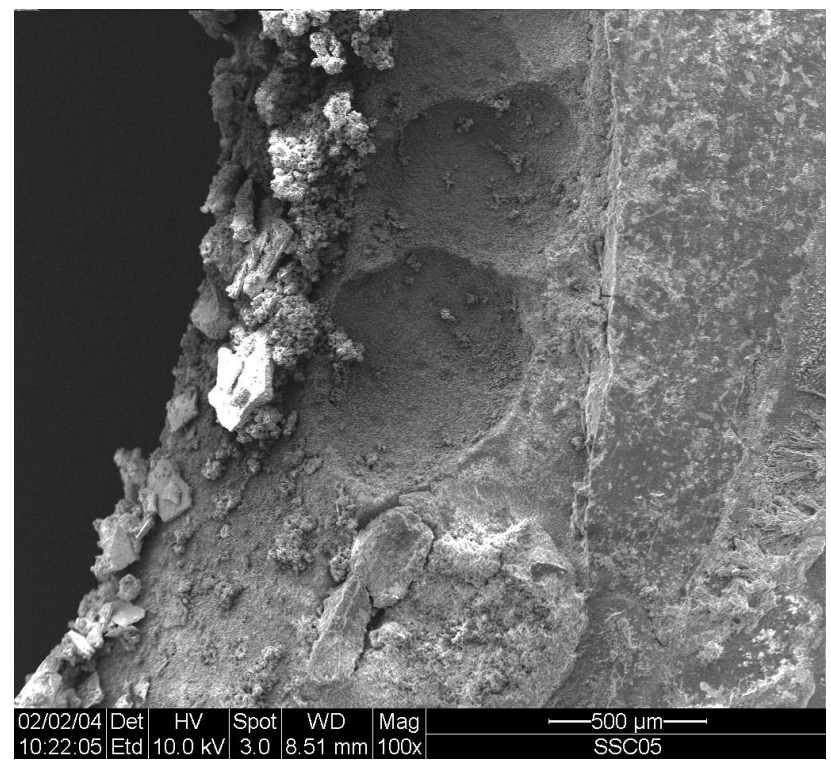

Figure 4: Annulus of SSC-05 in SAW, Liquid for $5+$ Years

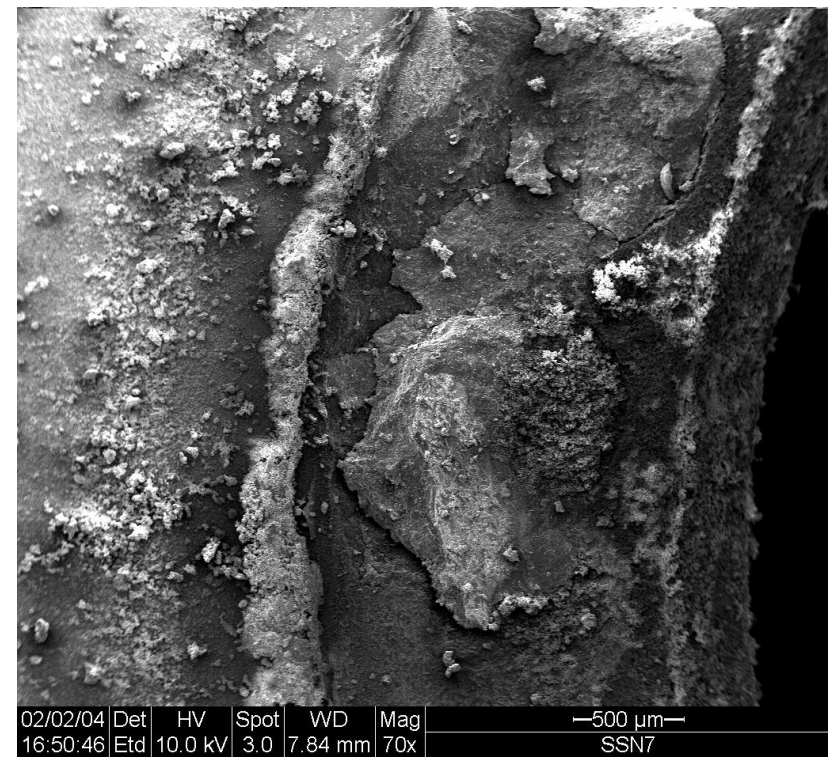

Figure 5: Annulus of SSN-07 in SAW, Liquid for $5+$ Years

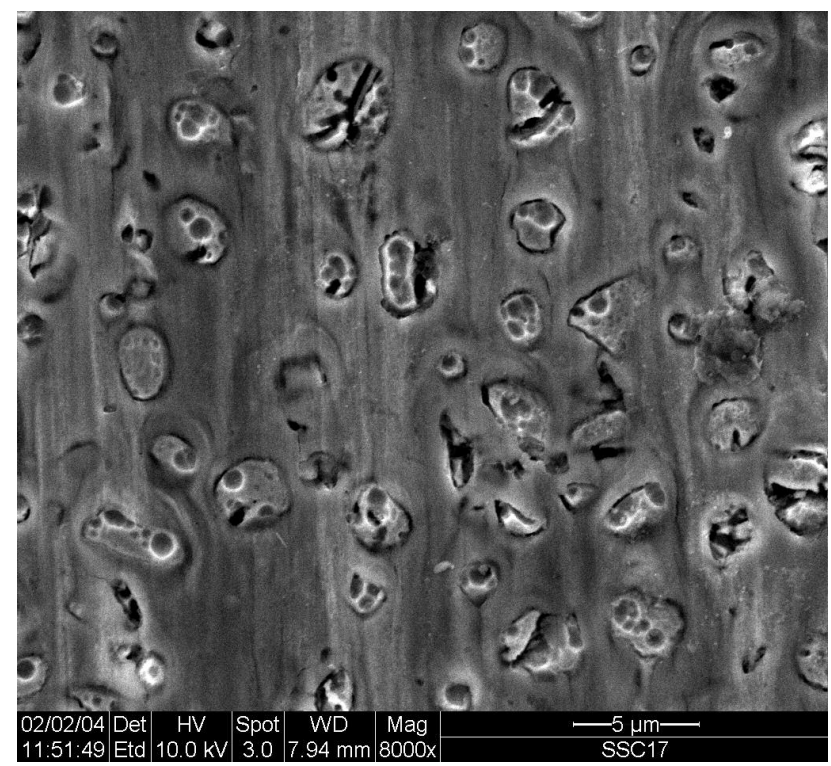

Figure 6: Bold Surface of SSC-17 in SCW, Liquid for $5+$ Years 